\title{
ANALISIS MULTIPLIER EFFECT PAJAK, INVESTASI DAN PENGELUARAN PEMERINTAH TERHADAP PERTUMBUHAN EKONOMI KALIMANTAN TIMUR
}

\author{
Erni Setiawati, Rudy Syafariansyah \\ Dosen Universitas Widya Gama Mahakam Samarinda \\ erni@uwgm.ac.id \\ Lita Furiawan, Karin Setiani, Herdi Nirwany \\ Mahasiswa Universitas Widya Gama Mahakam Samarinda
}

\begin{abstract}
Abstrak
Tujuan penelitian ini adalah untuk mengukur besarnya koefisien angka pengganda (multiplier effect coefficient) pajak, investasi dan pengeluaran pemerintah dan dampaknya terhadap pertumbuhan ekonomi Provinsi Kalimantan Timur. Pengumpulan data menggunakan sumber data sekunder yang berasal dari data publikasi oleh Badan Pusat Statistik (BPS) Provinsi Kalimantan Timur.

Jenis penelitian adalah deskriptif kuantitatif. Metode analisis menggunakan model persamaan Keseimbangan Perekonomian, yaitu $\mathrm{Y}=\mathrm{C}+\mathrm{I}+\mathrm{G}$ dengan alat analisis Multiplier Effect Coefficient, yang terdiri dari multiplier pajak $\left(\mathrm{k}_{\mathrm{T}}\right)$, multiplier investasi $\left(\mathrm{k}_{\mathrm{I}}\right)$ dan multiplier pengeluaran pemerintah $\left(\mathrm{k}_{\mathrm{G}}\right)$. Variabel yang diamati/diukur adalah tingkat PDRB, tingkat konsumsi rumah tangga masyarakat, total nilai investasi baik swasta dan pemerintah, serta besarnya pengeluaran pemerintah.

Penelitian menunjukkan nilai multiplier effect pajak $\left(\mathrm{k}_{\mathrm{T}}=-0,28\right)$ Makna dari angka pengganda pajak tersebut $(-0,28)$ artinya adalah bahwa kenaikan pajak sebesar 1 satuan akan mempengaruhi/menyebabkan berkurangnya pendapatan sebesar Rp. 0,28 . Nilai multiplier effect investasi $\left(\mathrm{k}_{\mathrm{I}}=1,28\right)$ sama dengan multiplier effect pengeluaran pemerintah $\left(\mathrm{k}_{\mathrm{G}}=1,28\right)$. Makna angka pengganda investasi dan pengeluaran pemerintah sebesar 1,28 artinya adalah bahwa kenaikan atau penambahan investasi dan pengeluaran pemerintah sebesar Rp. 1 maka akan mempengaruhi/menyebabkan kenaikan pengeluaran agregat $(\mathrm{Y}=\mathrm{PDRB})$ sebesar $\mathrm{Rp}$. 1,28 .
\end{abstract}

Kata Kunci : multiplier effect, pajak, investasi, pengeluaran pemerintah

\section{Pendahuluan}

Dampak positif dari ekonomi global adalah kecenderungan menguatnya perdagangan dunia (trade of world), dan akibatnya adalah peningkatan produksi barang/jasa (output) negara-negara berkembang. Harga komoditas terutama migas dan 
energi mengalami peningkatan, hal ini juga berpengaruh pada perekonomian Kalimantan Timur, yang mulai menggeliat dan tumbuh mencapai nilai positif.

Berdasarkan hasil Berita Resmi Statistik (BRS) Februari 2018 oleh BPS Provinsi Kalimantan Timur, Perekonomian Kaltim triwulan II 2018 tumbuh 1,84\% (yoy). Pertumbuhan ekonomi Kaltim sejalan dengan pergerakan ekonomi nasional yang tumbuh 5,27\% pada triwulan II 2018. Ditinjau dari segi lapangan usaha, kinerja perekonomian Kaltim didorong oleh pertumbuhan lapangan usaha konstruksi serta penyediaan akomodasi dan makan \& minum.

Berdasarkan komponen pengeluaran, pertumbuhan ekonomi Kaltim ditopang oleh kinerja investasi, khususnya subkomponen investasi bangunan. Indikator lain yang menunjukkan peningkatan investasi adalah realisasi investasi langsung dalam negeri yang juga meningkat. Tolak ukur yang biasa digunakan untuk melihat hasil kinerja perekonomian daerah adalah nilai Produk Domestik Bruto (PDRB) nya. Produk Domestik Regional Bruto (PDRB) atau bisa juga disebut sebagai output daerah, dan merupakan indikator mengukur pertumbuhan ekonomi suatu daerah. PDRB menggambarkan pendapatan agregat suatu daerah dalam kurun waktu/periode tertentu, berdasarkan sektor/lapangan usaha, dan sektor pengeluaran. Perubahan PDRB dari periode satu ke periode lainnya akan menunjukkan pertumbuhan ekonomi suatu daerah.

PDRB juga merupakan konsep pendapatan nasional untuk daerah provinsi/kabupaten. Nilainya bisa berubah, tergantung dari perubahan pengeluaran agregatnya (AD). Perubahanperubahan ini bisa dijelaskan dengan konsep angka pengganda (multiplier). Angka pengganda (multiplier) adalah suatu angka/nilai pelipatgandaan yang menerangkan seberapa besar pendapatan nasional $(\Delta \mathrm{Y})$ berubah akibat dari berubahnya pengeluaran agregatnya. Dalam perekonomian tiga sektor perubahan pengeluaran agregat bukan saja ditentukan oleh perubahan investasi (I), tetapi juga ditentukan oleh pajak (T) dan pengeluaran pemerintah $(\mathrm{G})$. Jadi dengan konsep multiplier effect bisa diukur seberapa besar dampak atau pengaruh perubahan investasi, pajak dan pengeluaran pemerintah terhadap PDRB.

Berdasarkan uraian di atas, maka kami mengambil judul penelitian ini adalah Analisis Multiplier Effect Pajak, Investasi, dan Pengeluaran Pemerintah, terhadap Pertumbuhan Ekonomi Kalimantan Timur.

\section{Metode Penelitian}

Jenis penelitian ini adalah deskriptif kuantitatif, di mana penelitian ini menggambarkan determinan pertumbuhan perekonomian (PDRB) Kaltim melalui pengolahan data-data kuantitatif, yang diperoleh dari data yang dirilis oleh pihak berwenang (BPS).

Sumber data dan cara memperolehnya adalah data eksternal dan data sekunder. Data eksternal diperoleh dari data yang dipublikasikan oleh Badan Pusat Statistik (BPS) Provinsi Kalimantan Timur. Sedangkan data sekunder yang dikumpulkan berupa :

1) Data PDRB Provinsi Kalimantan Timur tahun 2010 s/d 2018

2) Data tingkat konsumsi Provinsi Kalimantan Timur tahun 2010 s/d 2018

3) Data nilai total investasi (swasta dan pemerintah) Provinsi Kalimantan Timur tahun 2010 s/d 2018

4) Data pengeluaran pemerintah Provinsi Kalimantan Timur tahun 2010 s/d 2017 


\section{Gambar : Kerangka Penelitian}

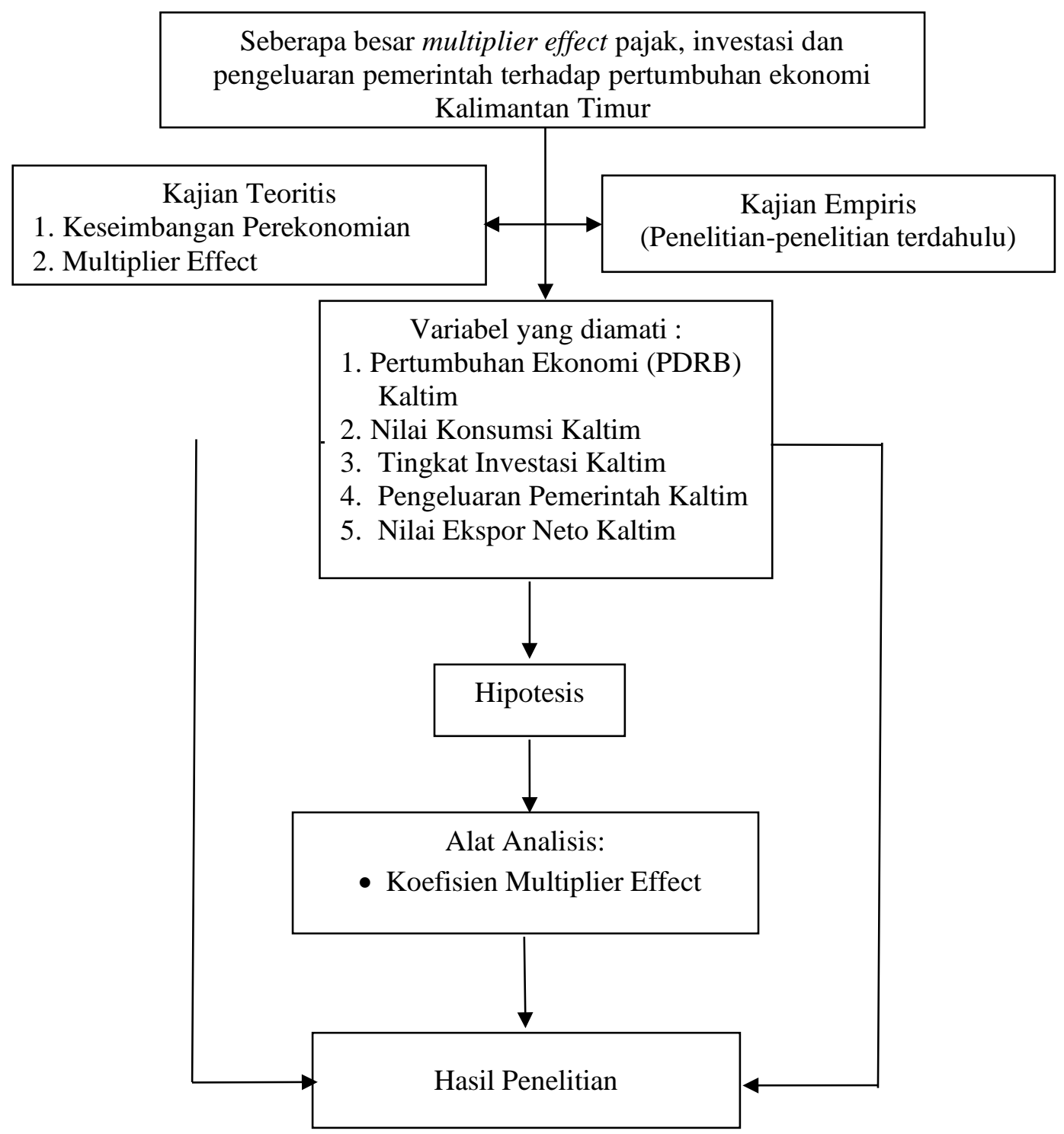


Alat analisis yang digunakan dalam penelitian ini adalah angka pengganda dari pajak, investasi dan pengeluaran pemerintah (multiplier effect coefficinet), dengan rumusan sebagai berikut :

1) Multiplier Investasi $\left(\mathrm{k}_{\mathrm{I}}\right)$.

Rumus : $\mathrm{k}_{\mathrm{I}}=\frac{1}{1-\mathrm{MPC}}$

2) Multiplier Pengeluaran Pemerintah $\left(\mathrm{k}_{\mathrm{G}}\right)$

Rumus : $\mathrm{k}_{\mathrm{G}}=\frac{1}{1-\mathrm{MPC}}$

3) Multiplier Pajak ( $\left.\mathrm{k}_{\mathrm{T}}\right)$

Rumus : $\mathrm{k}_{\mathrm{T}}=-\frac{\mathrm{MPC}}{1-\mathrm{MPC}}$

\section{Hasil dan Pembahasan}

Alat analisis dalam penelitian ini menggunakan angka pengganda (multiplier effect coefficient) dari pajak, investasi dan pengeluaran pemerintah. Tahapan awal untuk melihat efek pengganda (multiplier effect) dari pajak, investasi dan pengeluaran terhadap pertumbuhan ekonomi (PDRB) Kaltim, maka perlu dibuat asumsi-asumsi dan fungsi linier dari Fungsi Konsumsi, yaitu persamaannya adalah $\mathrm{C}=\mathrm{a}+\mathrm{bY}$, di mana : $\mathrm{C}=$ tingkat konsumsi (pengeluaran agregat)

$\mathrm{Yd}=$ Pendapatan Daerah

a $=$ konstanta, (nilai $\mathrm{C}$ jika $\mathrm{Yd}=0$ ) atau disebut $\mathrm{C}_{0}$

$\mathrm{b}=$ koefisien dari $\mathrm{Yd}$

Tabel 1 : Data Pengolahan Fungsi Konsumsi (Regression)

\begin{tabular}{ccccc}
\hline \multirow{2}{*}{ Tahun } & $\begin{array}{c}\text { PDRB } \\
\text { (dalam Juta } \\
\text { Rupiah) }\end{array}$ & $\begin{array}{c}\text { Konsumsi Rumah } \\
\text { Tangga } \\
\text { (dalam Juta Rp) }\end{array}$ & $\begin{array}{c}\text { Pengeluaran } \\
\text { Investasi } \\
\text { (dalam Juta Rp) }\end{array}$ & $\begin{array}{c}\text { Pengeluaran } \\
\text { Pemerintah } \\
\text { (dalam Juta Rp) }\end{array}$ \\
\hline $\mathbf{2 0 1 0}$ & 383293002.21 & 51059096.90 & 97159066.34 & 14013989.57 \\
\hline $\mathbf{2 0 1 1}$ & 472780553.03 & 57527377.45 & 111083544.44 & 15108733.82 \\
\hline $\mathbf{2 0 1 2}$ & 503402031.81 & 65493370.52 & 124671825.84 & 17342813.74 \\
\hline $\mathbf{2 0 1 3}$ & 519131868.87 & 73396421.73 & 129083647.03 & 20281615.33 \\
\hline $\mathbf{2 0 1 4}$ & 527515256.10 & 80180286.67 & 139830347.87 & 23523174.00 \\
\hline $\mathbf{2 0 1 5}$ & 505105062.08 & 86563223.85 & 145766483.58 & 25079715.17 \\
\hline $\mathbf{2 0 1 6}$ & 508880236.50 & 90750792.91 & 144794383.71 & 24143516.00 \\
\hline $\mathbf{2 0 1 7}$ & 592279940.26 & 96785580.00 & 154503230.00 & 21092790.00 \\
\hline $\mathbf{2 0 1 8}$ & 638116899.82 & 103435770.00 & 173413130.00 & 23195230.00 \\
\hline
\end{tabular}

Sumber : Pengolahan Data Sekunder, 2019 
Hasil pengolahan data sekunder di atas, menghasilkan persamaan Fungsi Linier dari konsumsi, yaitu : $\mathrm{C}=-35734595,77+0,22 \mathrm{Y}$. Dari persamaan tersebut dapat dilihat bahwa besarnya MPC adalah 0,22 artinya setiap tambahan pendapatan (PDRB) sebesar Rp. 1 milyar akan menambah pengeluaran konsumsi rumah tangga sebesar Rp. 220 juta. Sedangkan besarnya MPS adalah $1-$ MPC, yaitu $1-0,22=0,78$ artinya setiap tambahan pendapatan (PDRB) sebesar Rp. 1 milyar akan menambah tabungan sebesar Rp. 780 juta.

Nilai MPS lebih besar dari MPC, hal ini mengindikasikan bahwa tingkat konsumtif masyarakat rendah, dan mereka lebih memilih menggunakan pendapatan untuk ditabung, atau melarikan pendapatan mereka ke lembaga-lembaga keuangan, sehingga dana investasi terakumulasi lebih besar.

1) Multiplier Pajak

Perhitungan:

$$
\begin{aligned}
& \mathrm{k}_{\mathrm{T}}=-\frac{\mathrm{MPC}}{1-\mathrm{MPC}} \\
& \mathrm{k}_{\mathrm{T}}=-\frac{0,22}{1-0,22}=-\frac{0,22}{0,78}=-0,28
\end{aligned}
$$

Makna dari angka pengganda pajak sebesar -0,28 artinya adalah bahwa kenaikan pajak sebesar Rp. 1 akan mempengaruhi/menyebabkan berkurangnya pendapatan sebesar Rp. 0,28 Misalnya pajak naik sebesar Rp. 1 milyar, maka akan mengurangi pendapatan sebesar Rp. 280 juta. Perubahan pendapatan akan mempengaruhi/mengurangi tingkat konsumsi rumah tangga ( $\mathrm{C}$ ) dan dampaknya akan mempengaruhi/menyebabkan penurunan pengeluaran agregat $(\mathrm{Y}=\mathrm{PDRB}$ menurut pengeluaran).

Angka pengganda pajak bertanda negatif. Hal ini menunjukkan hubungan yang berlawanan arah. Jika terjadi kenaikan nilai pajak, maka akan mengurangi tingkat pendapatan, begitu pula sebaliknya, jika tarif pajak turun maka pendapatan akan naik.

Jika pajak naik, masyarakat cenderung mengurangi tingkat konsumsiny, karena pendapatan masyarakat pasti mengalami penurunan, sehingga tingkat konsumsinya juga cendeung berkurang. Tingkat konsumsi rumah tangga yang berkurang, juga berpengaruh terhadap pengeluaran agregat khususnya pengeluaran untuk investasi dan pengeluaran pemerintah yang akan mengalami kenaikan.

Pajak juga akan berpengaruh terhadap tabungan. Jika kondisi konsumsi masyarakat naik karena pajak, maka akan berdampak pada tabungan masyarakat yang akan mengalami penurunan, namun jika pajak naik dan dikenakan pada barang-barang konsumsi, maka akibatnya tingkat konsumsi akan turun, namun tabungan masyarakat akan mengalami kenaikan, dan dampak lainnya adalah bertambahnya nilai investasi.

Investasi mengalami kenaikan, dikarenakan meningkatnya pendapatan masyarakat yang tidak dihabiskan untuk konsumsi dilarikan ke lembaga-lembaga keuangan dalam bentuk tabungan. Tabungan ini menjadi dana investasi bagi sektor swasta atau bisnis. Begitu hal nya dengan pengeluaran pemerintah untuk pembiayaan 
pembangunan infrastruktur sebagai pengeluaran investasi bagi pemerintah. Investasi infrastruktur bertujuan sebagai stimulator percepatan pembangunan ekonomi.

2) Multiplier Pengeluaran Pemerintah

Perhitungan:

$\mathrm{k}_{\mathrm{G}}=\frac{1}{1-\mathrm{MPC}}$
$\mathrm{k}_{\mathrm{G}}=\frac{1}{1-0,22}=\frac{1}{0,78}=1,28$

Makna angka pengganda pengeluaran pemerintah sebesar 1,28 artinya adalah bahwa kenaikan atau penambahan pengeluaran pemerintah sebesar Rp. 1 maka akan mempengaruhi/menyebabkan kenaikan pengeluaran agregat $(\mathrm{Y}=\mathrm{PDRB})$ sebesar $\mathrm{Rp}$. 1,28. Misalnya pengeluaran pemerintah bertambah sebesar Rp. 1 milyar, maka akan mempengaruhi atau menyebabkan kenaikan PDRB sebesar. 1.280.000.000,-

Pengeluaran pemerintah selain untuk pembelanjaan belanja pegawainya, juga ada untuk pembiayaan pembangunan. Pembiayaan pembangunan ini sama dengan pengeluaran investasi, karena dana investasi digunakan untuk pembangunan infrastruktur yang diharapakan dapat menggerakkan dan mempercepat pembangunan ekonomi.

3) Multiplier Investasi

Rumus :

$\mathrm{k}_{\mathrm{I}}=\frac{1}{1-\mathrm{MPC}}$

$\mathrm{k}_{\mathrm{I}}=\frac{1}{1-0,22}=\frac{1}{0,78}=1,28$

Makna dari angka pengganda pengeluaran investasi sama dengan angka pengganda pengeluaran pemerintah sebesar 1,28 artinya adalah bahwa kenaikan atau penambahan pengeluaran untuk investasi sebesar Rp. 1 maka akan mempengaruhi/menyebabkan kenaikan pengeluaran agregat $(\mathrm{Y}=\mathrm{PDRB})$ sebesar $\mathrm{Rp}$. 1,28. Misalnya investasi bertambah sebesar Rp. 1 milyar, maka akan mempengaruhi atau menyebabkan kenaikan PDRB sebesar. 1.280.000.000,-

Pengeluaran investasi bagi dunia bisnis adalah suatu modal percepatan pertumbuhan bisnisnya. Investasi adalah modal, baik dalam bentuk finansial maupun barang modal, merupakan suatu cara untuk mengembangkan bisnis dengan tujuan menghasilkan keuntungan yang maksimal. Tanpa investasi mustahil bisnis akan berkembang. Investasi juga turut berperan dalam pengembangan ekonomi sehingga percepatan pertumbuhan ekonomi yang positif, dan meningkat bisa tercapai

\section{Kesimpulan dan Rekomendasi}

Berdasarkan hasil penelitian, analisis dan pembahasan, kesimpulan dari penelitian kami adalah sebagai berikut : 
1) Besarnya nilai multiplier effect pajak $\left(\mathrm{k}_{\mathrm{T}}=-0,28\right)$ Makna dari angka pengganda pajak tersebut $(-0,28)$ artinya adalah bahwa kenaikan pajak sebesar 1 satuan akan mempengaruhi/menyebabkan berkurangnya pendapatan sebesar Rp. 0,28.

2) Besarnya nilai multiplier effect investasi $\left(\mathrm{k}_{\mathrm{I}}=1,28\right)$ sama dengan multiplier effect pengeluaran pemerintah $\left(\mathrm{k}_{\mathrm{G}}=1,28\right)$. Makna angka pengganda investasi dan pengeluaran pemerintah sebesar 1,28 artinya adalah bahwa kenaikan atau penambahan investasi dan pengeluaran pemerintah sebesar Rp. 1 maka akan mempengaruhi/menyebabkan kenaikan pengeluaran agregat $(\mathrm{Y}=\mathrm{PDRB})$ sebesar Rp. 1,28.

Multiplier effect pajak memiliki nilai yang negatif, artinya dampak dan pengaruhnya berbanding terbalik dengan tingkat pendapatan (PDRB). Oleh karena itu saran kebijakan bagi pemerintah daerah adalah untuk benar-benar memperhitungkan tarif serta objek yang dikenakan pajak. Pemerintah dalam menyusun kebijakan fiscal harus benar-benar mengedepankan keberpihakan kepada masyarakat kecil, sehingga kekayaan dan pembangunan tidak hanya dinikmati dan mengalir hanya pada satu golongan saja.

Multiplier effect investasi dan pengeluaran pemerintah memiliki nilai yang positif, artinya investasi dan pengeluaran pemerintah memiliki dampak yang searah terhadap tingkat pendapatan (PDRB). Pemerintah dalam menyusun APBD harus benar-benar mengalokasikan anggaran untuk investasi dan pengeluaran pada proyekproyek padat karya yang banyak menyerap lapangan pekerjaan. Sehingga pengannguran bisa berkurang, pendapatan bisa meningkat, daya beli meningkat, dan pada akhirnya akan mempengaruhi pendapatan nasional secara umum

\section{Daftar Pustaka}

Karya, Detri. Syamsuddin, Syamri. 2017. Makro Ekonomi; Pengantar Untuk Manajemen. Rajawali Pers.Jakarta

Kilateng, Febriani, dkk. 2017. Analisis Multiplier Effect Agribisnis Tomat Terhadap Perekonomian Di Desa Tonsewer Selatan Kecamatan Tompaso Barat. eJournal Agri-Sosio Ekonomi, Universitas Sam Ratulangi, Manado.

Muhidin, Sambas Ali. 2011. Panduan Praktis Memahami Penelitian. Pustaka Setia. Bandung

Murni, Asfia. 2016. Ekonomika Makro; Edisi Revisi. Reflika Aditama.Bandung Raharja, Prathama. 2008. Teori Ekonomi Makro; Suatu Pengantar. Lembaga Penerbit Fakultas Ekonomi UI. Jakarta

Rosyidi, Suherman. 2012. Pengantar Teori Ekonomi; Pendekatan Kepada Teori Ekonomi Mikro dan Makro. Edisi Revisi. Rajawali Pers. Jakarta 
Sugiyono. 2003. Metode Penelitian Bisnis, Pusat Bahasa Departemen Pendidikan Nasional. Bandung

Sukirno, Sadono. 2010. Makro Ekonomi; Teori Pengantar. PT. Raja Grafindo Persada. Jakarta

Sukma, Andrio Firstiana. 2015. Efek Pengganda Infrastruktur PU Dalam Perekonomian Provinsi Bali. Journal of Regional and City Planning ITB, Bandung.

Supranto, J. 2008. Statistik Teori dan Aplikasi. Erlangga. Jakarta

Suseno, Deky Aji. Anas, Muhammad Azwar. 2017. Multiplier Effect Sektor Basis Terhadap Perekonomian Daerah Provinsi Jawa Tengah. Jurnal Riset Ekonomi Pembangunan, Universitas Tidar, Magelang. 